\title{
クエン酸水溶液中でキシロースより生成される微量のフルフラールの蒸留*
}

碇

\author{
醇**·村田 公 子** \\ 鹿児島大学工学部 化学工学科
}

\section{藉 䡒}

微量のフルフラールを含む、比较的希薄なェタノール 水溶液を単蒸留すると, 最初に仕込み液の数倍の泿度の フルフラールが留出してくるが, 留出率の增加とともに フルフラールの浱度む低下する”。しかし，すろみの蒸 留試験の結果は, これとまったく反対で, 蒸留の初期に はフルフラールは留出せず, 蒸留の後期になって急速に フルフラールの濃度が大きくなる2゙。これらのことから， フルフラールは, るろみの中のペントースまたはペント サンから，反応によって生成し，留出してくるすのと推 定される。

著者らは，若干の予備実験を行い,フルフラールの生 成と蒸留を調べる祭には、エタノールは一応除外して考 えてよいのではないかといらことを示しだ2。

ここでは, るろみの蒸留を行う際の, フルフラールの 生成と蒸留を考察する基礎的研究として，むろみの中に 含まれる代表的な有機酸であるクエン酸の水溶液の中 で, 少量のキシロースが反応してフルフラールが生成 し, 留出してくる速度を測定した。

そして,この反応の機構を仮定し, 蒸留速度を組み合 わせた，微量成分の反応蒸留の速度式を作成し，実験テ 一タから反応速度定数を定めた。

さらに, 少量のキシロースを添加したクエン酸水溶液 の単蒸留試験を行い, フルフラールの蒸留曲線が, 上記 の速度式を用いて，よく表されることを明らかにした。

\section{1. 実験方法}

実験に使用した D-キシロース,クエン酸は特級試薬， 水汢蒸留水である。

\section{$1 \cdot 1$ フルフラールの平衍比の測定}

微量 $(0.02 \sim 0.03 \mathrm{wt} \%)$ のフルフラールを含むクエ ン酸水溶液を, オスマーの装置の液相部に仕込み, 常法 によってフルフラールの平衡比を求める。クエン酸の濃 度を变えて，測定を行った。

\section{$1 \cdot 2$ 単蒸留鯧験}

1）缶液量を一定にして蒸留した場合 $300 \mathrm{ml}$ の 共通すり合わせ三つロフラスコの, 片方のロに目盛付分

* <Distillation o: a Minute Amount of Furfural Formed from Xylose in an Aqueous Solution of Citric Acid> Received on June 15, 1973 化学工学協会第 6 回秋乎大会 (東京, 1972 年 11 月) て笔夷

** Atsushi Ikari (正会員) and Kimiko Murata (正会员) Dept. of Chem. Eng., Kagoshima Univ., Kagoshima, Japan
液沪斗をつけ，中央の口には枝管をつけて冷却器に連結 する。所定量のキシロースと水をフラスコに入れる。分 液沪斗には，投入したとき所定の濃度になるよう科量し たクエン酸を, $7.5 \mathrm{~N}$ の濃度の水溶液にして入れる。

フラスコの上部はガラス綿で保温する。マントルヒー ターでフラスコを加熱する。蒸留中は, マントルヒータ 一にかける電压を一定にして，蒸留速度が変動しないよ らにした。沸騰が始まる直前に，分液沪斗のクエン酸を フラスコに投入し，反応を開始させる。

蒸留が始まると, 分液沪斗より水を滴下し, 蒸留によ ってフラスコ内の液が減少するのを補充して, 掖量を 一定に保つ。留出液は一定量ずつ小試験管に分取し, 科 量したのち分析する。

2）缶夜が減少するままにして蒸留した場合 蒸留 の進行に伴って缶液が減少するので，この場合は $1 l$ の 三つロフラスコを使用し，水の滴下は行わない。このは かは 1) と同様である。

\section{$1 \cdot 3$ 分 析}

微量成分フルフラールの分析は, 前報1) と同様, 四光 光度法（フニリン法）によって行った。

\section{2. 実験結果およひ考察}

\section{$2 \cdot 1$ フルフラールの平衡比}

クエン酸水溶液中での, 微量のフルフラールの平衡比 $K_{\mathbb{F}}\left(=y_{F} / x_{F}\right)$ を求めた結果を Fig. 1 亿示す。なお, 液相でのフルフラールのモル分率 $x_{\mathrm{F}}$ は， $1.5 \sim 6.0$ $\times 10^{-5}$ の範囲にある。後述の計算で使用するため, Fig. 1の曲線を下記のように数式化しておく。ただし， $C$ はクエン酸の濃度 $(N)$ である。

$$
\begin{aligned}
K_{F}= & 7.48-7.3844 C+2.3751 C^{2}+0.88839 C^{3} \\
& -0.69645 C^{4}+0.11106 C^{5}
\end{aligned}
$$

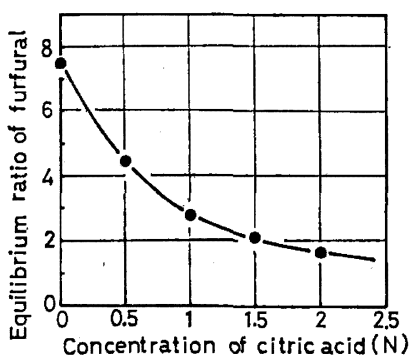

Fig. 1 Equilibrium ratio of a minute amount of furfural 


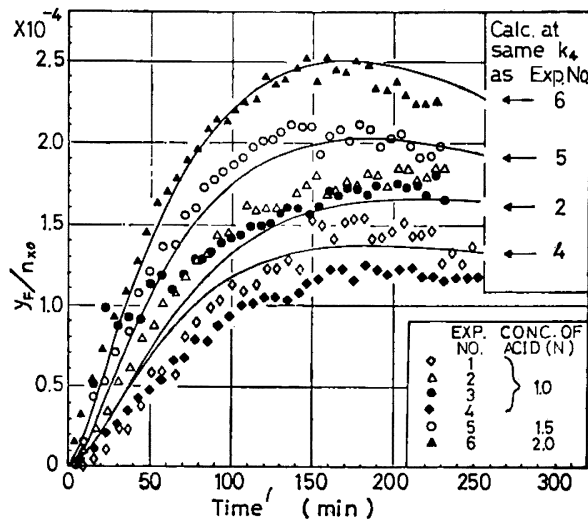

Fig. 2 Experimental results of Exp. No. 1 6 and calculated ones of Eqs. (5) (8)

\section{$2 \cdot 2$ 単蒸留圾験の結果}

単蒸留試験は, Table 1 に示すような条件で行った。 得られた結果を, Figs. 2〜4 と示す。

実験 No. 1 6 6, 缶液量を一定にして繁留した場合 であり，キシロースの仕込量 $n_{\mathbf{x} 0}$ あるいはクエン酸 濃度を変えて実験したものである。仕込み量を增加すれ ば，留出液中のフルフラールの濃度 (モル分率) $y_{\mathrm{r}}$ も增 加するので，Fig. 2 では，縦軸を $y_{\mathbf{F}} / n_{\mathbf{X} v}$ で示してい る。

実験 No.7,8は, 午液が減少するままにして蒸留し た場合であり，蒸留速度を変えて実験したものである。

Fig. 3 は留出量に対して，Fig. 4 は時間に対して，留 出液中のフルフラール濃度をプロットした。

以上の各実験について, 留出量を時間に対してブロ, トすると，ほとんど直線上にのる，すなわち蒸留中は一 定速度で留出していることがわかる。この值線を逆に延 長して，横軸との交点を求め $t=0$ とした。Table 1 の蒸留速度は, この直線の傾きから求めたむのであ る。

\section{$2 \cdot 3$ 考 察}

前節で, クェン酸水溶夜中でのフルフラールの平衡比 を求めた。ここで取り报ら系は, クェン酸水溶液に少量 のキシロースを加えた系であるが，このような系に括け るフルフラールの平衡比を測定することは困難であり， また推算法もみあたらない。Table 1 に示したように, キシロースの量はクェン酸に比べると少量であるので, 後述の計算には，ここで得た $K_{\mathbf{E}}$ をそのまま使用す る。

次に, Fig. 2 の実験 No. 1 4 4, クェン酸濃度を一 定にしてキシロースの仕込み量を変えたものであるが， 200 分位たって $y_{\mathbb{F}} / n_{x 0}$ がほぼ一定になったところを比 較すると，その高さの順序は実験 No. で 2, 3, 1, 4 であ る。これは, 仕込み量の順序ではなくて, 蒸留速度の順
Table 1 Experimental conditions

Weight of Xylose charg- Initial Distillation the charge ed to still conc. of rate, $\eta$ Exp. Distillation [8] ${ }^{2} \times 10^{9} \quad$ citric acid mol

\begin{tabular}{|c|c|c|c|c|c|}
\hline & & & {$[\mathrm{mol}]$} & {$[N]$} & $L$ min \\
\hline 1 & \multirow{6}{*}{$\begin{array}{l}\text { Liquid in still } \\
\text { is maintained } \\
\text { constant }\end{array}$} & 300 & 3.993 & 1.0 & 0.0948 \\
\hline 2 & & 300 & 9.987 & 1.0 & 0.0867 \\
\hline \multirow{4}{*}{$\begin{array}{l}3 \\
4 \\
5 \\
6\end{array}$} & & 300 & 15.98 & 1.0 & 0.0891 \\
\hline & & 300 & 22.00 & 1.0 & 0.1083 \\
\hline & & 300 & 9.983 & 1.5 & 0.0923 \\
\hline & & 300 & 9.983 & 2.0 & 0.0943 \\
\hline \multirow{2}{*}{$\begin{array}{l}7 \\
8 \\
\end{array}$} & \multirow{2}{*}{$\begin{array}{l}\text { Liquid in still } \\
\text { remains as it } \\
\text { decreases }\end{array}$} & 800 & 10.01 & 0.6 & 0.0919 \\
\hline & & 800 & 10.13 & 0.6 & 0.1406 \\
\hline
\end{tabular}

序であり，蒸留速度が速くなるとこの高さは低くなる。 このことから，反応速度とともに，蒸留速度が影響する ことがわかる。

実験 No. 2, 5, 6 を比較すると，触媒濃度を高くすれ ば，反応速度が大きくなり， $y_{F} / n_{\mathbf{X} 0}$ が高くなることが わかる。

Figs. 3 と 4 (実験 No.7と 8) Kは，蒸留速度の違い か，留出液のフルフラール濃度に及活す影䇾について示 されている。

\section{3. 反応の機構と速度式}

\section{$3 \cdot 1$ 反芯の機構}

ヘンントースからフルフラールを生成する反応には，多 くの中間体が考えられており ${ }^{32}$ ，また Schoenemann ら ${ }^{4,5)}$ の研究もあるが，本報で取り扱っている弱酸中で の反応には，そのまま適用することは困難である。

本節の目的は，反応によって微量成分が生成し，留出 する場合の, 反応速度と蒸留速度を含んだ数式モデルを 作成し，実験で得られた蒸留曲線を説明すること，そし て, 留出液中の微量成分フルフラールの濃度が，単蒸留 の操作条件である蒸留速度によって变化する有様を明ら かにすることにある。そこで，この目的にかなう限り， できるだけ簡単な反応機構を仮定することにする。

そこで，最初はキシャースからフルフラールへといら 単純な 1 次反応からはじめ, 実測値と対比させて試行錯 誤を繰り返して，少しずつ複雑にしていく。このような 方法で、いま次のようなメカニズムを仮定する。

$$
\begin{aligned}
& \text { キシロース (X) } \stackrel{k_{1}}{\longrightarrow} \text { 中間体 }(\mathrm{I}) \stackrel{k_{2}}{\longrightarrow} \text { フルフラール (F) } \\
& k_{3} \\
& \text { 樹脂 (R) 留出液中の } \\
& \text { フルフラール }
\end{aligned}
$$

\section{$3 \cdot 2$ 速度式}

このメカニズムに従って速度式を作ると，次式のよう になる。

$$
\begin{aligned}
& \mathrm{d} n_{\mathrm{Z}} / \mathrm{d} t=-k_{1} n_{\mathrm{X}} \\
& \mathrm{d} n_{\mathrm{I}} / \mathrm{d} t=k_{1} n_{\mathrm{X}}-\left(k_{2}+k_{\mathrm{B}}\right) n_{\mathrm{I}} \\
& \mathrm{d} n_{\mathrm{F}} / \mathrm{d} t=k_{2} n_{\mathrm{I}}-K_{\mathrm{F}} \eta n_{\mathrm{F}} / L
\end{aligned}
$$


Fig. 3 Experimental results of Exp. No.7 and 8 , and comparison with calculated results

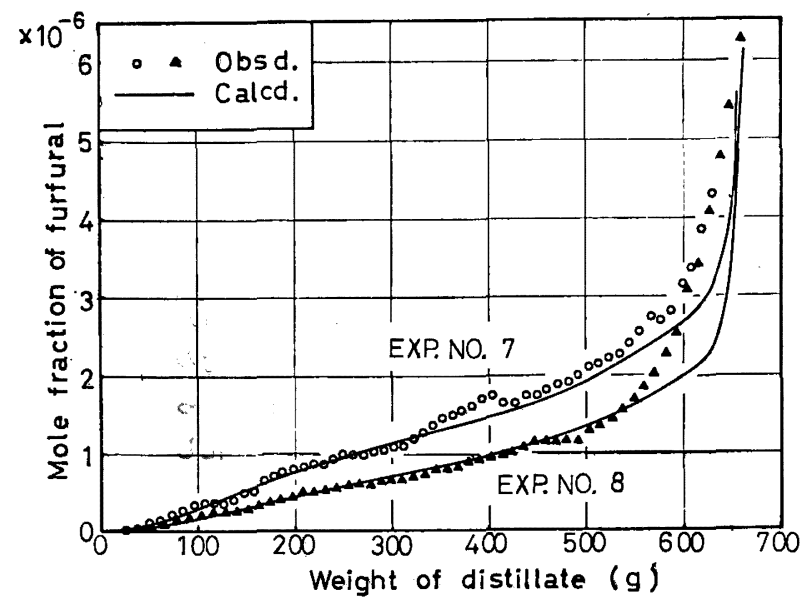

Fig. 4 Experimental results of Exp. No.7 and 8, and comparison with cal. culated results

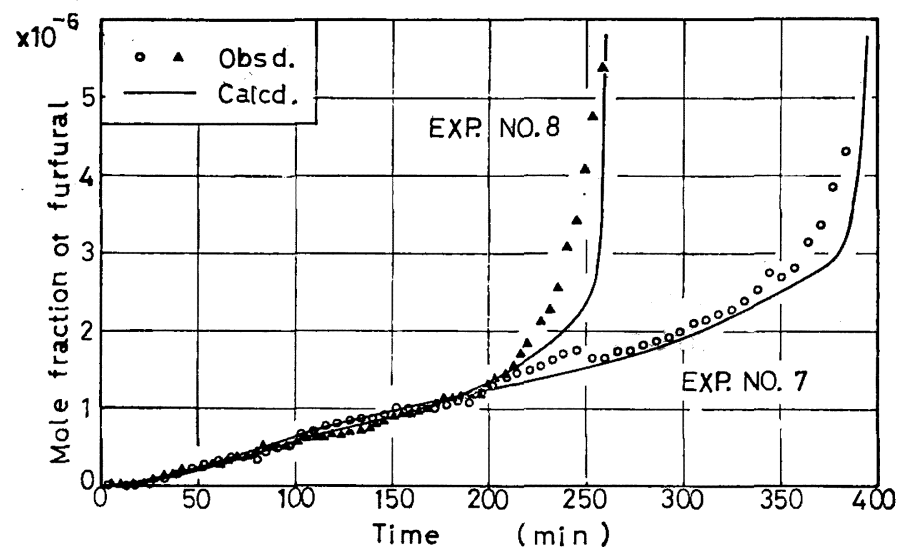

$$
y_{\mathrm{F}}=K_{\mathrm{F}} x_{\mathrm{F}}=K_{\mathrm{F}} n_{\mathrm{F}} / L
$$

Eq.（3）は，缶液のフルフラールの增加速度が, 中間 体からの生成速度と，缸からの留出速度の差であること を表している。留出速度は，蒸留速度 クと気相に拈け るモル分率 $y_{F}$ との積である。Eq. (4) は, フルフラー ルの気夜平衡関係を示している。

\section{$3 \cdot 3$ 反応速度定数}

実験 No. 1 6のように, 缶液量 $L$ を一定にして蒸留 すれば，触媒であるクエン酸の濃度は変わらないから， $k_{1}, k_{2}, k_{3}, K_{\mathrm{F}}$ は一定である。 $K_{\mathrm{F}} \eta / L \equiv k_{4}$ と拈いて, Eqs.（1)〜（3）を解けば,

$$
\begin{aligned}
& \frac{y_{\mathrm{F}}}{n_{\mathrm{X} 0}}=\frac{K_{\mathrm{F}}}{L} \cdot \frac{k_{1} k_{2}}{\left(k_{2}+k_{3}\right)-k_{1}}\left\{\frac{e^{-k_{1} t}-e^{-k_{4} t}}{k_{1}-k_{1}}\right. \\
&\left.-\frac{e^{-\left(k_{3}+k_{3}\right) t}-e^{-k_{4} t}}{k_{4}-\left(k_{2}+k_{3}\right)}\right\}
\end{aligned}
$$

この式の中の $k_{4}$ は，実験で得られた る值である。そこで，Fig. 2 に示された実測値に合らよ 5に, $k_{1}, k_{2}, k_{3}$ を求めていく。すなわち, Fig. 2 亿示 した実測值から, 時間 $t_{1}, t_{2}, t_{3}$ における $y_{F} / n_{X_{0}}$ の值 $Y_{1}, Y_{2}, Y_{3}$ を読んで，それぞれを Eq. (5) 飞代入する
と， $k_{1}, k_{2}, k_{3}$ を末知数とする 3 元連立方程式ができ る。コンピニーターを用いて， 3 元ニュートン法により これを解き， $k_{1}, k_{2}, k_{3}$ の数值を求める。何組かの（ $t_{1}$, $\left.t_{2}, t_{3}\right)$ Kついて計算し，その平均をとる。

次に, $k_{1}, k_{2}, k_{3}$ は触媒であるクェン酸の濃度の関数 であるからこれらの関係を示す実験式を求める。い ま，三つのクエン酸濃度について得られた $k_{1}, k_{2}, k_{3}$ を 両対数グラフにプロットすると,クエン酸濃度による㑯 向がかかる。これを 3 本の線で示し, これから得た $k_{1}$, $k_{2}, k_{3}$ の值を Eq. (5) に代入して得られた曲線を Fig. 2 の実測值と比較する。実測值と合うように，グラフ上 の線を若干移動し修正した。

ごく荒い近似の機構を仮定しており，かつ実測值には 相当の誤差があるから，充分に合致させることは困難で あるが，得られた線を式で示すと，次のようになる。

$$
\left\{\begin{array}{l}
k_{1}=0.001148 C^{1.78} \\
k_{2}=0.0006398+0.0001545 C^{2.5} \\
k_{3}=0.05012 C^{1.395}
\end{array}\right.
$$

これらの式から得られる $k_{1}, k_{2}, k_{3}$ の値と, Table 1 に示した Exp. No. 2, 4, 5, 6 のクの值を用いて求めた 
$k$ 、を、Eq. (5) 飞代入し，得られた曲線を Fig. 2 に示 した。この罒をみると，実測值とよく似た曲線群が得ら れていることがわかる。

\section{4. 反応を伴う単蒸留}

\section{$4 \cdot 1$ 蒸留計算}

少量のキシロースを含むクエン酸水溶液を単蒸留する 場合には, 蒸留の進行ととるに缶液の量 $L\left(=L_{0}-\eta t\right)$ は減少していく。クエン酸の量 $n_{C}$ は一定だから，その 濃度 $C\left(\fallingdotseq 3,000 n_{\sigma} / 18.02 L\right)$ は大きくなる。それに伴っ $\tau, k_{1}, k_{2}, k_{3}, K_{\mathrm{F}}$ は，前に記載した式に従って变化し ていく。

これらの関係を用いて，Eqs. (1) （3）の連立微分方 程式を数値的に解けば, Eq. (4) によって留出液のフル フラール濃度を求めることができる。

計算には，九州大学大型計算機センターの FACOM 230-60 を用い, ルンゲークッタージル法のサブルーチン ライブラリーを使用した。

\section{$4 \cdot 2$ 計算結果と考察}

Table 1 に示した実験 No. 7, 8 のデータを代入して, 上記の計算を行った結果を Figs. 3，4 に示した。

初めは $800 \mathrm{~m} l$ で, クエン酸瀑度が $0.6 \mathrm{~N}$ であった缶 液が, 蒸留が進行して, $200 \mathrm{ml}, 2 \mathrm{~N}$ 位になってくると, 計算値は実測値に合わなくなるが，それまでは両者はよ い一致を示している。

クエン酸濃度が大きくなると, 反応はさらに複隿にな

り３・1で仮定した簡単な機構では合わなくなること や, 速度定数や平衡比を定める実験を, クエン酸濃度 $2 \mathrm{~N}$ までしかやっていないことなどの理由で，計算値と 実験値のずれが生しててきたのと思わ机る。

しかし，もろみの蒸留においては，これ以前にェタノ ールは完全に留出してしまい,このようなところまで蒸 留を続けることはないから，これ以上の追求は無意味で あるのでやらなかった。

\section{結言}

ここで取り扱った系は，反応を伴ら微量成分の蒸留の
一例である。

このような蒸留においては，反応と蒸留とを連結した メカニズムを考え，速度式を考え，これを数値的に解く ことによって, 実測值とかなりよい一致を示す蒸留曲線 が得られることを明らかにした。

また，緒言で述べた蒸留酒の製造の際の、フルフラー ルの挙動を説明することができ，単式蒸留機の操作に一 つの指針を与えることができると思われる。

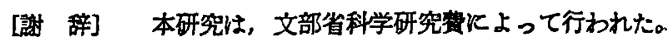
ここと記して感謝の意を表します。

\section{Nomenclature}

$C=$ concentration of citric acid $\quad[N]$

$K=$ equilibrium ratio $[-]$

$k_{3}, k_{2}, k_{3}=$ reaction rate constant $\quad\left[\mathrm{min}^{-1}\right]$

$k_{1}=K_{\mathrm{F}} \eta / L \quad\left[\mathrm{~min}^{-1}\right]$

$L=$ quantity of liquid in still [mol]

$n=$ quantity in still [mol]

$t=$ time [min].

$x \quad=$ mol a fraction in liquid phase $[-]$

$y=$ mole fraction in vapor phase $[-]$

$\eta=$ distillation rate $[\mathrm{mol} / \mathrm{min}]$

<Subscripts>

c = citric acid

$\mathbf{F} \quad$ = furfural

I = intermediate

$x=x y l o s e$

0 = initial

\section{Literature cited}

1) Ikari, A. and S. Toya: Kagaku Kogaku, 35, 1131 (1971)

2) Ikari, A.: Jorrya Gijutsu (Distillation Tech.), 1, 41 (1971)

3) "Mokuzai Kagaku Kogyo (Wood Chem. Ind.)", p.128, Noguchi Inst, Seibunda-Shinkosha (1961)

4) Schoenemann, K. and H. Hoffmann: Chem. Ind. Techn 29, 665 (1957)

5) Schoenemann, K.: Chem. Eng. Sci, 14, 39 (1961) 